\title{
Hamsa
}

H俞MSA Journal of Judaic and Islamic Studies

2 | 2015

Varia

\section{The poetics of the scenography of power: the embassy of Yahya al-Ghazāl to Constantinople}

\section{Elsa Cardoso}

\section{Q OpenEdition \\ 1 Journals}

\section{Electronic version}

URL: https://journals.openedition.org/hamsa/801

DOI: $10.4000 /$ hamsa.801

ISSN: 2183-2633

\section{Publisher}

CIDEHUS - Centro Interdisciplinar de História Culturas e Sociedades da Universidade de Évora

\section{Electronic reference}

Elsa Cardoso, "The poetics of the scenography of power: the embassy of Yahya al-Ghazāl to Constantinople", Hamsa [Online], 2 | 2015, Online since 31 December 2015, connection on 13 May 2021. URL: http://journals.openedition.org/hamsa/801 ; DOI: https://doi.org/10.4000/hamsa.801

\section{(ब) $\oplus \Theta$}

Hamsa est mise à disposition selon les termes de la Licence Creative Commons Attribution - Pas d'Utilisation Commerciale - Pas de Modification 4.0 International. 


\title{
The poetics of the scenography of power: the embassy of Yahyya al-Ghazāl to Constantinople*
}

\author{
Elsa Cardoso \\ Associate researcher of the Centre for \\ History of the University of Lisbon \\ elsa.fc@gmail.com
}

\section{Resumo:}

Este artigo discute características cerimoniais da primeira embaixada cordovesa enviada a Constantinopla por 'Abd al-Raḥmān II, amìr do al-Andalus. A embaixada é o resultado de uma missão enviada pelo imperador bizantino, Teófilo, a Córdova em 225 A.H. (ca. 839/840 A.D.). Tendo em consideração que a embaixada de al-Ghazāl em Constantinopla não pretendia a cimentação de uma aliança política, esta é normalmente descartada pelos historiadores como apenas contendo elementos "anedóticos," indignos de comentários. Contudo, as situações descritas revelam importância cerimonial. Poesia, como parte integrante to protocolo ritualizado, gestos cerimoniais e situações, cujo palco é a corte bizantina, serão discutidos.

Palavras-chave: al-Andalus; Diplomacia; Cerimonial; Bizâncio; Orientalização.

\begin{abstract}
:
This article discusses ceremonial features of the first Cordovan embassy sent to Constantinople by 'Abd al-Rahmān II, amir of al-Andalus. It is the result of a mission sent by the Byzantine Emperor Theophilos to Cordoba in 225 A.H. (ca. 839/840 A.D.). As al-Ghazāl's mission to Constantinople does not have the intent of drawing a political alliance, it is usually dismissed by historians as only containing "anecdotic" accounts not worth to be commented. However, situations described reveal ceremonial significance. Poetry within the ritualized protocol, ceremonial gestures and events taking place at the Byzantine court of Theophilos will be discussed.
\end{abstract}

Key words: al-Andalus; Diplomacy; Ceremonial; Byzantium; Oriental influence.

After Theophilos sent the first Byzantine embassy to Cordoba in 839/840, 'Abd al-Rahmān II commissioned al-Ghazāl and al-Munayqila to escort him to the Byzantine capital where they were also to deliver the missive from the amir to Theophilos. Yahya bin Hakam al-Bakrī, nicknamed al-Ghazāl, because of his beauty (al-Ghazāl means gazelle, an attribute given to both women and young boys), was a poet and courtier who was born in Jaen during 'Abd alRaḥmān II's reign and died under the rule of Muhammad I (852-886). ${ }^{1}$ His companion and 
homonymous, Yahya, called Șāhib al-Munayqilla (the man with the little clock), ${ }^{2}$ is not known to us. Ibn Hayyān does not convey more biographical data than his name and nickname.

The chapter describing both the requisition of al-Ghazāl by the amir to carry out this diplomatic task and his stay in Constantinople is presented by Ibn Ḥayyān before the account reporting the arrival of Qūrtiyyus, ambassador of Theophilos, and the description of 'Abd alRaḥmān's missive. ${ }^{3}$ This is easily explained, as Ibn Hayyān compiled previous works. This account has been acknowledged by Lévi-Provençal as describing "interesting and picturesque details, as well as attractive anecdotes". ${ }^{4}$ Thus, the lack of description concerning the reception of Qūrtiyyus' embassy oppose to al-Ghazāl's mission in Byzantium, which possesses extensive anecdotes. Due to its "anecdotic" nature this account is usually neglected by scholars who do not manage to find historical, ceremonial and political meaning in it, choosing often not to describe it nor to comment on it.

Though some caution may be expected from researchers, there are events described in this account that arise interest regarding ceremonial and its influence from the East. At first, Ibn Hayyān accounts poems composed by the courtier who, because of his advanced age, was trying to be exonerated from his mission, most of them in a sarcastic tone, describing his badtempered wife whom he equals to an ogre due to her aging. ${ }^{5}$ So, 'Tsa bin Aḥmad al-Rāzī, from whom Ibn Hayyan copies this account, and who speaks of it as having witnessed most of these events, seems more worried to entertain the audience, as in fact was the poet's aim, than to give an accurate description of the events, though they are still relevant. Other verses follow in Ibn Ḥayyān's account with this intention. Nevertheless, these did not help al-Ghazāl, as 'Abd alRaḥmān II was resolute to send him.

Ibn Hayyan's account proceeds to describe the ambassadorial route to Constantinople, first by land and then by sea. The Andalusi historian informs that the "secret message" of the amir was delivered to the "tyrant". ${ }^{6}$ Then he accounts the stratagem of al-Ghazāl, who escapes from prostrating at Theophilos' feet, and a presumable burglary of a fine glass by the poet. I will discuss both events further ahead, as I shall first argue the importance of poetry, and in this specific case al-Ghazāl's poetry, in court ceremonial and ambassadorial receptions.

Scenic events with Theophilos' consort, Theodora, about whom al-Ghazāl composed odes to her beauty, and with the crown prince, Michael, are described. Al-Ghazāl was known in the court of Cordoba as an innovator who brought new poetry styles to al-Andalus, while being in Iraq, where al-Hakam I and his son and successor 'Abd al-Rahmān II kept informers or agents. This can be perceived through accounts, such as the trader who Ibn Hayyan mentions to have attended a ceremony at the 'Abbasid court, where the governor of Egypt, 'Abd Allāh bin Ṭāhir, showed his appreciation towards al-Ghazāl's recitation of a type of poetry innovated by himself called ta'in or confession of impotency. ${ }^{7}$

\footnotetext{
* This article consists of a chapter of the MA dissertation of its author, "Diplomacy and oriental influence in the court of Cordoba $\left(9^{\text {th }}-10^{\text {th }}\right.$ centuries)", under the supervision of Professor Hermenegildo Fernandes, PhD.

${ }^{1}$ Ibn Hayyān, Crónicade los emires al-Hakam I y 'Abd ar-Rahman II entre los años 796 y 847 [al-Muqtabis II-1], trans. Mahmud 'Ali Makki and Federico Corriente, Zaragoza, Instituto de Estudios Islámicos y del Oriente Próximo, 2001, 144, 244.

2 Huici Miranda, "al-Ghazal, Yahya bin Hakam al-Bakri", in Encyclopaedia of Islam, ed. B. Lewis et al., vol.

2, C-G, Leiden: E.J. Brill, 1991, 1038.

${ }^{3}$ Ibn Ḥayyān, al-Muqtabis II-1, 228-244.

4 Évariste Lévi-Provençal, "España Musulmana, hasta la caída del califato de Córdoba (711-1031 J.C.)," in Historia de España, ed. Ramón Menéndez Pidal, vol. IV, Madrid, Espasa-Calpe, 1982, 163.

${ }^{5}$ Ibn Ḥayyān, al-Muqtabis II-1, 229.

6 Ibid., 236.

${ }^{7}$ Ibid., 146.
} 
Though he became known while he was young in al-Hakam I's court by his panegyric style, ${ }^{8}$ later on his easiness and integration in the court were such that he developed a satirical tone, and most of his poetry is labelled by Ibn Ḥayyān as "festive" and of "pleasantry". This granted him quite a few enemies, especially in the circles of religious groups of the court, such as those of the fuqaha', who accused him of being an atheist. ${ }^{9}$ His satirical poetry towards Ziryāb, Iraqi musician and courtier who enjoyed preferential treatment by the amir, also granted him banishment from al-Andalus, which ironically provided him with a visit to Iraq, where he learnt the poetic models of great eastern masters. ${ }^{10}$ For poets such as al-Ghazāl, who was not even ashamed to depreciate his own sexual attributes by developing the style of "confessing impotency", transgressing social standards was permissible and he made plenty use of this privilege, accusing the fuqaha' to enrich through obscure ways at the expenses of Islam.

When 'Abd al-Raḥmān II "asked" al-Ghazāl to accompany the Byzantine ambassador, the poet, who was already septuagenarian, requested to be dismissed from this task, which involved travelling and time. It is in this passage that al-Ghazāl refers to a previous ambassador sent to Constantinople, which would antagonize Ibn Hayyan's own account that this exchange was the first amongst the Umayyads of Cordoba and the Byzantines. With this allusion, alGhazâl intended to be dismissed from his mission, suggesting that the amir should send "the other", whose name was Ibn Abī Tilbah, in his turn - "and he alluded maliciously to the ambassador who was sent before to the country of the Byzantines". ${ }^{11}$ This could be referring to an ambassador sent right after the reception of Qūrtiyyus, who later, upon his returning, was accompanied by al-Ghazāl and al-Munayqila. Perhaps the two ambassadors were to be reunited with a first one sent to Theophilos. Nevertheless, this is just speculation as we do not possess other sources mentioning a previous embassy.

Thus, the amir seems to have chosen al-Ghazāl because of his skills regarding spoken and written word. The poet wrote:

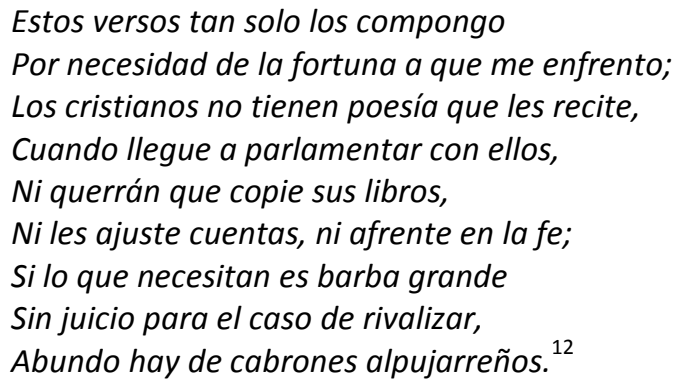

The poem, though intended to dismiss al-Ghazāl from his ambassadorial task, as Christians did not appreciate poetry, paradoxically and subtly makes the praise of al-Ghazāl qualities as poet, scholar and possessing a beard, an attribute for wise men, whose type, nevertheless, alGhazāl believed to prolifically exist in Alpujarras (mountain region of southern al-Andalus). However, the Umayyad was determined in his preference for al-Ghazāl, most probably because such a courtier, proficient in the art of poetry and wordplay, would achieve with success the ungrateful task of presenting the emperor with the polite answer which transpired the negative of 'Abd al-Raḥmān II's reply in acting with Byzantium against Andalusi

\footnotetext{
8 Ibid., 142.

${ }^{9}$ Ibid., 144, 149.

${ }^{10}$ Al-Maqqarī, The History of the Mohammedan Dynasties in Spain. Nafh al-tib min ghosnī al-Andalusī alRatīb wa Tārīkh Lisān ad-Dīn Ibn al-Khațīb, trans. Pascual de Gayangos, vol. II. London, Oriental Translation Fund, 1843, 116.

${ }^{11}$ Ibn Hayyān, al-Muqtabis II-1, 229- 230.

12 Ibid., 231. Poems accounted will remain in its Spanish translation, as I do not feel comfortable to translate poetry.
} 
adventurers in the Mediterranean, who conquered Crete around 826/827. In fact, one of alGhazāl's verses seems to allude to 'Abd al-Raḥmān II's aim to acknowledge friendly relations with Byzantium, but at the same time refusing to act jointly:

Se olvidaron de mí cuando había esperanza, Pero ante lo ingrato me empujan ${ }^{13}$

Nonetheless his stubbornness, al-Ghazāl was reassured by the amir who conceded his family plenty of donations and qata'i (rents), which he begged from the amir, by means of his poetry. ${ }^{14}$

Poetry played a central role in court culture as well as in ceremonies, such as receptions of ambassadors. In fact, sources describing ulterior receptions give to poets and intellectual men a central role in court ceremonial, as they were commissioned to speak eloquently about the sovereign and his power, and to show knowledge of eastern masters. They were expected to present to the audience and the Caliph, seated centrally in his sarì (throne), a qașida praising his power, and further attaching to the rich scenic tapestry stage, composed by Quraysh family members, hujjāb, wuzarā', kuttāb, eunuchs and others, carefully placed by order of precedence, a veneration atmosphere. Sometimes this worship, luxurious, and at the same time rigorous set, was such a heavy feast for the eyes and heart that even the poet would stammer and "was soon reduced to silence by the terror that this most imposing scene produced in his mind". ${ }^{15}$ On the same occasion, al-Maqqari reports that a poet named Mundhir bin Sa'id was chosen to address the audience, revealing his poetic attributes, which earned him the office of qā $\bar{d} \bar{i}$ al-jama. So, the court and even its most meticulously drawn ceremonies presented to poets an opportunity to shine in the eyes of the representative of the divine, the sovereign, the highest of the patrons of arts, who appointed poets for administrative offices, based on their poetic skills, which were strongly associated to their political expertise.

The vivid ceremonial image accounted in al-Maqqarī history, though reporting to later days of the Umayyad dynasty, during the caliphate of 'Abd al-Rahmān III, evidently had its roots under the rule of 'Abd al-Raḥmān II. Ibn Hayyān describes 'Abd al-Raḥmān II as the first sovereign who introduced pomp in al-Andalus: "Abd al-Rahmān II was the first of the marwanid caliphs who gave splendour to the monarchy in al-Andalus, assigning it with pomp and majesty, conferring to it a reverential feature and electing the right men for each function". ${ }^{16}$

The majlis where these receptions took place in Madinna al-Zahrā' is a true stage of a theatrical play, coated with the finest tapestry and carved stucco, where order of precedence must be attended to and the magnificence and terror produced by this scenography of power was expected to be put into words by poets. This stage was indeed an "imitatio of divine creation" and the social order reproduced in it "mirrors the cosmic order". ${ }^{17}$ Poetry seems to be as well part of a puzzle set composed by three pieces: poetry, music and dancing. This was true for a more relaxed context in a courtly scenario, with cultural and amusement purposes, where drinking alcohol played a strong role. Oleg Grabar understands these semi-private ceremonies as an integral part of the court life, of which influences must be sought amongst

\footnotetext{
13 Ibid., 231.

14 Ibid., 229, 233.

${ }^{15}$ Al-Maqqarī, Nafh II, 138. The historian is reporting the account of a Byzantine embassy received in Cordoba in 336 A.H. (ca. 947).

${ }^{16}$ Ibn Hayyān, al-Muqtabis II-1, 171. The translation is mine.

17 Suzanne Stetkevych, The poetics of Islamic legitimacy: myth, gender and ceremony in the classical Arabic ode, Indiana, Indiana University Press, 2002, 246.
} 
Sassanid rulers, but not exclusively, as drinking and listening to music had been an almost mandatory connection for societies preceding the Umayyads. ${ }^{18}$

If solemn ceremonies such as receptions of ambassadors or religious festivities should be understood as an imitatio of divine creation, so poetic recitation, music and drinking ought not to be dismissed as mere relaxation environments, but assumed as part of an idyllic paradisiacal scenario, that of the janna', the Muslim paradise. Descriptions of this paradise are quite famous, where believers enjoying their family company and exquisite banquets served in priceless vessels, with the same pomp and magnificence as in a court, are provided with gardens adorned by fountains and rivers of milk, honey and wine, and drinking from it does not cause intoxication. ${ }^{19}$

As courtly complex ceremonies, such as a reception, seem to coexist with paradisiacal banquets showered with wine, the same phenomenon is transposed for poetry where panegyrics coexist simultaneously with the obscene style (mujun). Thus, as for a divine imitatio on earth, the educated society of the court could transgress Muslim prohibitions, such as that of wine drinking, as they were above the hierarchy, able to impersonate and attain paradise. Paradoxical ambivalence has been studied in the field of mujun poetry ${ }^{20}$ and it seems to occur frequently among medieval Muslim societies, especially among an elite of poets associated with court society, as poets seem to have enjoyed liberties not allowed to other courtiers. This is quite evident in the account of Ibn Ḥayyān, as he transmits a poem of al-Ghazāl to 'Abd alRaḥmān II that begins with praise style and then proceeds in the mujun style. The poet at first refers to the amir as the chosen one to rule both the East and the West, showing how alAndalus was well informed about apocalyptic rumours circulating in the East prophesying the end of the 'Abbasids, ${ }^{21}$ and made profit out of it, in order to claim its legitimacy:

\section{Dios no me libere, si no nos traes \\ A la memoria al buen 'Umar, \\ $Y$ el Oriente te ansía, \\ Con celos de Occidente 22}

Then the poet proceeds to expose his misfortunes caused by the prison, where he was then, and how frustrated he was by not being able to masturbate without feeling his chains. As the excerpt evidences, legitimacy was a central role of the panegyric style adopted by Muslim courts such as the Umayyad of Cordoba. It served clear political purposes of propaganda of the dynastic lineage of the Umayyads. It is not an accident that this legitimacy was fully achieved during 'Abd al-Raḥmān II's reign, described as the representative of "the first age of Andalucian culture". ${ }^{23}$

Poetry was indeed an exclusive and intrinsically Arabic art, dating back from a time previous to the coming of Islam. In jāhiliyya days, poets were part of a central set of the tribal identity and legitimacy, and this art developed and was inherited by urban and strongly educated court

\footnotetext{
18 Oleg Grabar, "Ceremonial and Art at the Umayyad Court," PhD diss., Princeton University, 1955, 8183.

19 L. Lockhart, "Djanna”, in Encyclopaedia of Islam, ed. B. Lewis et al., vol. 2, C-G, Leiden, E.J. Brill, 1991, 447.

${ }^{20}$ Miguel Boronha, "Male homosexuality in Islamic normative and in the mujun literature of al-Andalus and the Maghreb between the $10^{\text {th }}$ and $13^{\text {th }}$ centuries," MA diss., University of Lisbon, 2014.

${ }^{21}$ Eduardo Manzano, "Byzantium and al-Andalus in the ninth century," in Byzantium in the ninth century: Dead or alive?, ed. Leslie Brubaker, Hampshire, Ashgate Publishing, 1998, 223. Theophilos seems as well to have taken these claims as a way to convince 'Abd ar-Raḥmān II to join forces with him against a mutual enemy.

${ }^{22}$ Ibn Ḥayyān, al-Muqtabis II-1, 241.

${ }^{23}$ Kennedy, Muslim Spain and Portugal: a political history of al-Andalus, New York,Longman, 1996, 46.
} 
societies, where values of Bedouin ancestors were nothing but a memory. ${ }^{24}$ This specifically Arabic tradition was inherited by the first dynasty of caliphs of the Muslim Empire, the Umayyads of Damascus, who after their fall in the East transferred the literary genre of the panegyric qașida to al-Andalus "as an integral element of the courtly ceremony and the insignia of authority of the cultural hegemony of the Arab conquerors and of Arabo-Islamic rule". 25

This transition suffered by poetics and poets, from a tribal and Bedouin environment to a quite complex court society, is in fact assigned to the Umayyads of Damascus. Though their status in a tribal society is reported to have been a more freely one, they acquired a new prestige under Umayyad rule: from a position of "translators of the feelings and emotions" of the people, poets started to express emotions of an elite. ${ }^{26}$ This tradition was also preserved by the 'Abbasid court, as most of the poetry produced there was of praise style. As for alAndalus the panegyric to the ruler seems sometimes to be one of the faces of the same coin, as the other was the mujun style. In the $9^{\text {th }}$ and $10^{\text {th }}$ centuries the 'Abbasid court becomes the paradigm not only for Muslim courts but also for the Byzantine empire which centre emanates models that are to be followed by those who dream of surpassing it, as the Umayyads of Cordoba.

Indeed, the Umayyads, who once were the paradigm of models, now became receptors of a new one located in a Persian environment. In Ibn Ḥayyān's account of this embassy, the poet is reported as proficient in the use of Iraqi masters such as Abū Nuwās, ${ }^{27}$ poet and courtier of the 'Abbasid court, and was henceforth considered to be himself, al-Ghazāl, a master, due to his knowledge of the new paradigm of innovations. 'Abd al-Rahmmān II surrounds himself with groups of poets, similarly of what was practice in the court of Baghdad, where "golden dinars were showered on successful poets". ${ }^{28}$

Though it might be hard for nowadays Western societies to appreciate the aims of this praise poetic style, as Hugh Kennedy suggests, this can be easily understood when explained by a more westerner paradigm:

Perhaps we can see a parallel in the court portraiture of ancien régime monarchies in Western Europe. When we admire a heroic portrait, an image of Philip IV of Spain by Velázquez, for example, we know that Philip was a monarch with his share of imperfections and that the painter has made him look bolder and more impressive than he ever was in real life. But this apparent 'dishonesty' does not prevent us from appreciating the painting as a work of art. So it must have been for much of the audience for this praise poetry; of course it was exaggerated, but that did not detract from the skill of the poet or the imagination and originality of his compliments and comparisons. ${ }^{29}$

In a society where pictorial representation was a transgression, as no human soul should attempt to possess divine qualities of creation, what was later appreciated by the artistic eyes of $17^{\text {th }}$ century European court societies, was long before appreciated by the artistic ears of $9^{\text {th }}$ century Muslim court societies. As painting was a language of the Spanish court of the $17^{\text {th }}$ century, poetry was the ceremonial language of Muslim courts. ${ }^{30}$

\footnotetext{
${ }^{24}$ Hugh Kennedy, When Baghdad ruled the Muslim world. The rise and fall of Islam's greatest dynasty, United States, Da Capo, 2004, 113.

${ }^{25}$ Stetkevych, The poetics of Is/amic legitimacy, 254.

${ }^{26}$ Grabar, Ceremonial and Art at the Umayyad Court, 78, 79.

${ }^{27}$ Ibn Hiayyān, al-Muqtabis II-1, 233.

${ }^{28}$ Kennedy, The Prophet and the Age of the Caliphates, 147.

${ }^{29}$ Idem, When Baghdad ruled the Muslim world, 114.

30 Maribel Fierro, "Pompa y Ceremonia en los Califatos de Occidente Islámico (s. II/VIII-IX/XV)", Cuadernos del CEMyR, 17 (2009).
} 
As for the purpose of being dismissed of conducting the embassy to Constantinople, as well as for praising the empresses and her son's qualities, al-Ghazāl makes use of the poetry, art in which he was mastered and which was traditionally Arabic and develops under the patronage of the umarā' and caliphs.

Ibn Hayyan describes how once Theophilos received al-Ghazāl in his private chambers, where the empress was also attending, "bejewelled and groomed as a rising sun". ${ }^{31}$ As he was so lost in Theodora's beauty, he did not take any attention to Theophilos' words, and he was only forgiven due to the eulogy he made towards his wife, who started to act on al-Ghazāl's behalf, "obtaining from the king those objectives which were complicated". ${ }^{32}$ In the same passage, Ibn Ḥayyān describes how al-Ghazāl, who had a reputation of being greedy, asks that Theodora offers him some of her necklaces, so that he would be able to marry his daughters.

Another anecdote of al-Ghazāl's relation with the empress reports an episode where Theodora takes the liberty to present her son, presumably the crown prince Michael, future Michael III, to al-Ghazāl's private chambers:

I honour you by bringing my son to your side, the light of my eyes, to spend the night with you drinking and benefiting from your culture. ${ }^{33}$

Al-Ghazāl feels extremely flattered with this offer, but refuses on the grounds that his religion did not allow him to do so and, as he claimed, he disliked it. Hence, his "decency" appears to have pleased the emperor, who later heard of this story. Al-Ghazāl dedicated a poem to both Theodora and her son:

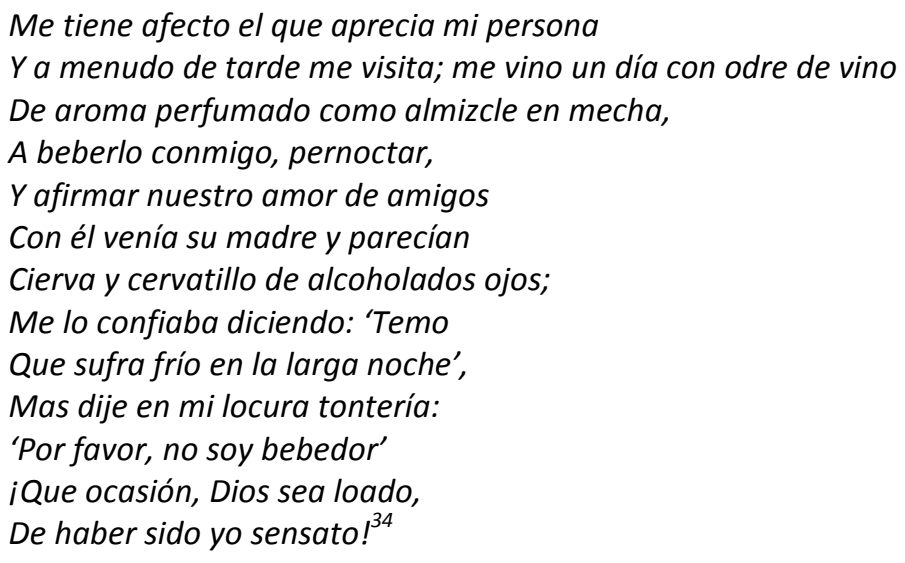

Though al-Ghazāl seems tempted to take part in what appears to be an initiation ritual, paradoxically he excuses himself with religious beliefs. If this in fact happened, or if it was only intended to detract the royal habits of the Byzantine court, it is not for us to determine. Thus, pederasty was a social-cultural behaviour typical of Classical Greece, and seems to be followed under Muslim culture. ${ }^{35}$

Anecdotes alluding to sexuality and pleasantry with the empress are multiple, but this is not the place to debate it further. Returning to the ceremonial around al-Ghazăl's reception in Constantinople, there are two episodes most relevant to be discussed here.

One concerns the first time al-Ghazāl was received by Theophilos in Constantinople, when presumably he handed over to the emperor the letter from 'Abd al-Rahmān II. As Theophilos

\footnotetext{
${ }^{31}$ Ibn H.̣yyān, al-Muqtabis II-1, 236.

${ }^{32}$ Ibid., 237. The translation is mine.

${ }^{33}$ Ibid., 237. The translation is mine.

${ }^{34}$ Ibid., 238.

${ }^{35}$ Boronha, Male homosexuality in Islamic normative, 86.
} 
knew that it was not customary for Muslims to bow when entering into the presence of the sovereign, he resorts to a trick: the door which gave access to the platform where the emperor was seated had been lowered, so that the ambassador was only able to cross it on his knees. ${ }^{36}$ As al-Ghazāl had previously been advised by the courtiers about what was customary in the Byzantine court, he complained and this was transmitted to the emperor, who resorted to this artifice of lowering the door. However, the same "anecdotic" account, reports al-Ghazāl escaping to this humility by entering the door on his back, which earned him compliments of the emperor, because of his sharpness.

Maribel Fierro, who addresses in an article what was customary during Western Muslim ceremonies in Medieval Islam, reports a quite similar event during the period of the governors of al-Andalus. 'Abd al-'Azīz, governor of al-Andalus of the $8^{\text {th }}$ century, is accused by military commanders of building such a door in his audience chamber, so that those entering his presence would bow before him, something that is accounted to have been an advice of his wife, widow of Rodrigo, last Visigoth king. This trick prompted his assassination. ${ }^{37}$

Bowing, at first was not accepted amongst Muslim sovereigns, even if the scenography of power was intended to attain a divine character. Indeed, bowing is perceived as an exclusive act reserved only for God, as shown by the ritual raka' or bowing which follows the recitation of the Quran while standing, during the șalā, or pray. As in Ancient Greece, the Muslim court societies, initially, do not accept the bowing before a sovereign. The habit of the proskynesis, ${ }^{38}$ or bowing, in Byzantium, seems to have its roots in the Persian ceremonial. References to proskynesis in Greek first appears in Herodotus or in Aeschylus when reporting Persian traditions in the court, and it seems to be introduced in Greece by Alexander the Great. ${ }^{39}$ Proskynesis also implied waving a kiss, while prostrating on the ground, which was unacceptable for the early Muslims, as it was before Alexander the Great introduced it in Ancient Greece.

The Rusūm Dār al-Khilāfa, of Hilāl al-Șābi', $11^{\text {th }}$ century chronicler who accounted 'Abbasid ceremonial rules and regulations customary in the $10^{\text {th }}$ century, states categorically that "it was not the practice of old for an amir, a wazir, or a high dignitary to kiss the ground when he entered the presence of the caliph"..$^{40}$ This practice was not accepted before the $10^{\text {th }}$ century. Most probably it was not customary before the coming of the 'Abbasids, who were influenced by the traditions of the Sassanid Persian court. He describes in the same passage how kissing the hand of the caliph, who would cover it with his sleeve to prevent it to be touched by mouth or lip, was replaced by prostrating on the ground. Al- Saābi' asserts that both kissing the hand and proskynesis were only customary towards someone considered of high rank by the caliph, who was acknowledging his position and doing him a favour. He also adds that in the past, "the members of Hashemite House kissed neither the hand nor the ground." Nevertheless, proskynesis and kissing the ground were adopted in receptions among the 'Abbasids, as al-Ṣābi', asserts that by his time kissing the hand had been replaced by kissing the ground:

Now, however, they [the courtiers] have joined the others in kissing the ground, except for a few who have continued to avoid this practice. ${ }^{41}$

\footnotetext{
${ }^{36}$ Ibn Hayyān, al-Muqtabis II-1, 238-9.

${ }^{37}$ Fierro, "Pompa y Ceremonia", 136.

${ }^{38}$ Signes, "Bizancio y al-Andalus en los siglos IX y X," in Bizancio y la Península Ibérica. De la Antigüedad Tardía a la Edad Moderna, ed. Inmaculada Pérez Martín and Pedro Bádenas de la Peña, Madrid, CSIC, 2004, 207. The author refers to proskynesis when reporting the episode of al-Ghazāl and the lowered door.

39 John A. Scott, "The Gesture of Proskynesis", The Classical Journal, vol. 17, no. 7 (1922), 403.

${ }^{40}$ Hilāl al-Șābi', Rusūm Dār al-Khilāfa.The Rules and Regulations of the 'Abbasid Court, trans. Elie A. Salem, Beirut: American University of Beirut, 1977, 29.

${ }^{41}$ Ibid., 29.
} 
Thus, the principle of not kissing the ground and bowing seems to be perceived by Hilāl as one that used to distinguish Muslim rulers and "others". Even though this practice was adopted during 'Abbasid times, some courtiers are reported to refuse to do so. This adoption, amongst others, is certainly due to influence received from Persian civilization, which they continued to rule, as the 'Abbasid civilizational area was centred in the former Persian Empire, as opposed to the Umayyad dynasty centred in Syria, former important stronghold of the Byzantine Empire.

This "innovation" does not seem to have expanded in Western Muslim territories, where instead kissing the hand was kept as customary and was usual when the sovereign received ambassadors. ${ }^{42}$ At least, not during most receptions. We do not possess a description of the ceremonial at ambassadorial receptions, for 'Abd al-Raḥmān II's rule. However, al-Maqqarī, $17^{\text {th }}$ century North African historian, reports the arrival of Byzantine ambassadors under the caliphate of 'Abd al-Rahmann III. In this account the ambassadors are not reported to have kissed neither the ground nor the caliph's hand, as al-Maqqari only states that after everyone was at his place, "the ambassadors were then introduced to the presence of the Khalif" and "they approached the throne, and delivered their credentials into the hands of the Khalif". ${ }^{43}$ For the same reception, Ibn 'Idhārī reports that when 'Abd ar-Raḥmān III received the Byzantine ambassadors in Cordoba, the envoys attempted to perform the gesture of proskynesis towards the caliph, but he halted them from doing so. ${ }^{44}$ Surely, the rejection of such an eastern tradition was intended as a statement by the Andalusi dynasty, as the orthodox Umayyad Caliphs of Damascus were unfairly deposed by the innovative 'Abbasids.

When John of Gorze was received by 'Abd al-Raḥmān III he did not perform the act of proskynesis. The caliph gave him the palm of his hand to be kissed, which he did, as it was considered in al-Andalus as a gesture only reserved for those whom the ruler intended to honour. Similarly, Ja'far bin 'Alī al-Andalusī, North African ruler submitting to the Umayyad caliphal authority, when being received at al-Zahrā' kissed the threshold of the hall and then proceeded towards the sarir, from where the caliph gave his hand to be kissed. ${ }^{45}$

However, it appears that the gesture of proskynesis is reported in al-Andalus for Christian Iberian embassies, although rejected by the Andalusi rulers and not customary for other foreign envoys such as North African rulers or Byzantines. Thus, it seems the prostration was gradually introduced it the Umayyad court, especially under the rule of al-Hakam II, however as a gesture strictly reserved for Christians tributaries. In his imagined account of an embassy received by al-Nāșir, Ibn 'Arabī reports that the Frankish ambassadors prostrated at the caliph's feet. Also, upon the reception of Bon Filio, count Borrell's ambassador, on 1 July 971, the envoy together with his companions executed the gesture of proskynesis towards Caliph al-Hakam II, until reaching the throne and kissing the ruler's hand, and then walking backwards in order not to turn their backs on the ruler. ${ }^{46}$ The same gesture had been performed by Ordoño IV, when Caliph al-Hakam II received king Ordoño IV in 963, at Madīna al-Zahrā'. The deposed sovereign of Leon is reported not only to have prostrated himself at the caliph's feet and kissed the ground, as he is also accounted to have performed the gesture of proskynesis to

\footnotetext{
${ }^{42}$ Fierro, "Pompa y Ceremonia", 137.

${ }^{43}$ Al-Maqqarī, Naf̣̣ II, 138.

${ }^{44} \mathrm{Ibn}$ 'Idhārī, Histoire de l'Afrique et de l'Espagen intitulée al-Bayyano'l-Mogrib, trans. E. Fagnan, vol. II, Algiers, Imprimerie Oriental Pierre Fontana, 1904, 353.

45 Juan, Abad de San Arnulfo, "La embajada del emperador de Alemania Otón I al califa de Córdoba Abderrahmán III. Vida de San Juan de Gortz," trans. Paz y Melia, Boletín de la Academia de Ciencias, Bellas Letras y Nobles Artes de Córdoba, 33 (1931), 147; Ibn Hayyān, Anales Palatinos del Califa de Córdoba al-Hakam II, por 'Isa Ibn Ahmad al-Razi, trans. Emílio García Gómez, Madrid, Sociedad de Estudios y Publicaciones, 1967, 70.

${ }^{46}$ Ibn Hayyān, Anales Palatinos, 46.
} 
'Abd al-Rahmmān III's grave in Cordoba. ${ }^{47}$ Proskynesis in al-Andalus seems to be practiced only by those Christian Iberian foreign missions arriving at Cordoba with the purpose of submitting as tributaries of the caliph. The proskynesis of Ordoño IV clearly intends to glorify the caliph's power over Christian principalities in the Iberian Peninsula, and therefore the amir al-mu'minin felt extremely powerful.

As for Byzantium, De Ceremoniis of Constantine VII Porphyrogennetos, in the chapter under the title "What is necessary to observe when a reception is held in the Great Hall of the Magnaura, when the rulers sit on the throne of Solomon", describes the protocol of the proskynesis. It states that when the foreign is led to the presence of emperors "he falls down on the ground making obeisance before the rulers". ${ }^{48}$ Nevertheless, De Ceremoniis when describing the reception of "Saracens" in Constantinople, does not refer to the proskynesis. ${ }^{49}$ It appears that Byzantine ambassadors in Baghdad might have been dismissed from performing proskynesis, as a diplomatic principle of reciprocity seems to have been followed between 'Abbasids and Byzantines. As 'Abbasid ambassadors, and presumably other Muslim envoys in Constantinople, were dismissed from the proskynesis, Byzantine messengers in Baghdad are reported to have also been dismissed of such gesture. Thus, Byzantine envoys feared that their performance of the prostration would demand that the caliph's envoys to the basileus would be obliged to execute the same gesture. ${ }^{50}$

In al-Andalus, eastern influence from the 'Abbasid court was undoubtedly adopted, and it served as a legitimacy weapon for aiming to surpass those they were trying to mimic. Nevertheless, it seems to have been developed a ceremonial of legitimacy to articulate its claims for the caliphate as the righteous and orthodox ones, as opposed to the innovations adopted in Baghdad that defied religious precepts.

Another "anecdote" in Ibn Hayyān's Muqtabis, concerning the reception of al-Ghazāl in Constantinople, reports an episode where the poet was invited to seat with the emperor. In this account, the emperor was astonished by al-Ghazall's action: after the poet asked for a glass of water, a glass of gold and pearls was offered to him and after finishing it and emptying the remainder, he kept it inside his sleeve. ${ }^{51}$ The emperor then ordered the interpreter to ask the reason why al-Ghazāl was acting like this, and al-Ghazāl answered:

It is a rule of our caliphs, of whom you are allied with, that if in their presence water is requested by a noble ambassador, and he is honoured with a fine glass, he may take it and after drinking from it, he does not give it back, usage that I have been following, but if it is not customary amongst you, I will return it. ${ }^{52}$

For scholars, this act is usually dismissed as a joke and associated with anecdotes that report al-Ghazāl's greediness. However, a description of Hilāl al-Șābi' shows similarities to this account by Ibn Hayyān. Al-Muhallabī, a wazìr of the 'Abbasid Caliph Mu'izz al-Dawla, upon returning to his river boat after his reception with the Caliph al-Muti' bi-Allāh, "was followed by a servant and a well-dressed and good looking Turkish ghuläm carrying, in one hand, a golden tray with a crystal jug covered with a dabiqi cover, and in the other hand, a drying towel". When he finished the water, the wazir returned the jug to the ghuläm, who was then ordered by the servant to go with the wazir who, puzzled with the situation, asked why:

\footnotetext{
47 Ibid., 161.

48 Constantine VII Porphyrogennetos, De Ceremoniis. The Book of Ceremonies, trans. Ann Moffat and Maxeme Tall, vol. 2, Canberra, Australian Association for Byzantine Studies, 2012, 566- 568.

49 Ibid., 583-584.

${ }^{50}$ Kennedy, When Baghdad ruled the Muslim world, 155.

${ }^{51}$ Ibn H. Hayyān, al-Muqtabis II-1, 239.

52 Ibid., 239. The translation is mine.
} 
Because, replied the servant, when such things leave the Residence it is not customary to return them. What I am now doing is in accordance with rules that have been set for me and it is not in my power to contravene them. The ghulām is now with you, and what he has is for you. ${ }^{53}$

Even though the event in which al-Ghazāl attended, and presumably took place in the palace, is slightly different from the account concerning the 'Abbasid wazir that took place outside the Residence (though in the enclosure of the palace), the similarity is also unquestionable. Thus, this account appears to be much more than an "anecdotic" one. It evidences how al-Ghazāl was informed about what it was customary to observe in the 'Abbasid court, though it escaped him that this would happen only once outside the palace. Hence, the main core of this 'Abbasid rule of attendance was transmitted.

Al-Ghazāl's knowledge of rules of attendance practiced in the 'Abbasid court is one of the many clues existing in Ibn Hayyān's Muqtabis, that leads to the conclusion that 'Abd alRaḥmān II reorganized the Andalusi court taking 'Abbasid models, which he knew due to agents he kept in the East and to scholars or traders who travelled frequently there. As for the organization of the offices inside the court, Mohamed Meouak's work evidences how the administration suffered changes upon innovations coming from the 'Abbasid East. ${ }^{54}$

Evidently, as poetry is intrinsically connected with the court, al-Ghazāl acknowledged practices concerning ceremonial, which granted him in al-Andalus his good reputation as a diplomat and 'Abd al-Raḥmān II's categorical and unchangeable choice.

\footnotetext{
${ }^{53}$ Al-Șābi', Rusūm, 56.

54 Mohamed Meouak, Pouvoir souverain, administration central et élites politiques dans l'Espagne ummayade $\left(I I^{e}-I V^{e} / V I I^{e}-X^{e}\right)$, Helsinki, Academia Scientiarum Fennica, 1999.
} 